\title{
Does Composition of Public Expenditure Matter for Economic Growth? Lessons from Sri Lanka
}

\author{
Mayandy Kesavarajab ${ }^{1}$
}

\begin{abstract}
In the context of surging public expenditure and crumbling output growth, the growth effects of public expenditure have provoked an extensive discussion in the economic and political arenas in Sri Lanka. Since 1977, both public expenditure and its composition have changed intensely and largely been accompanied by expansion in size of successive governments. Although it is difficult to determine whether Sri Lanka has reached its optimal size of public expenditure, understanding the growth effects of public expenditure would clearly link policy contributions made by public expenditure in spurring growth in Sri Lanka. The purpose of this study is to examine the growth effects of composition of public expenditure considering full implications of government budget constraints. This study considers public expenditure at a disaggregated level to isolate productive elements of public expenditure from the total. Accordingly, public expenditure on education, health, defence, agriculture and transport and communication are considered. These expenditure items are selected based on their share in total expenditure. This study found that the growth effects of public expenditure vary at disaggregated levels. A major finding showed that public expenditure in education, agriculture, transport and communication sectors is positively and significantly associated with economic growth while defence and health expenditure do not have any significant impact on growth. Given the high magnitude of positive and significant growth effects of public expenditure in the education sector, this study suggests reforming public expenditure in favour of human capital development is paramount to stimulate long-term growth in Sri Lanka.
\end{abstract}

Key Words: Public Expenditure, Economic Growth, Government Budget

JEL Classification: H50, O40, H6

\footnotetext{
${ }^{1}$ The author is currently serving as a Senior Economist at the Economic Research Department of the Central Bank of Sri Lanka. The author is grateful to Dr Katsushi Imai and Dr Yin-Fang Zhang of the University of Manchester, United Kingdom and anonymous reviewers for their valuable comments and suggestions in developing this research paper. The author also would like to thank Dr Chandranath Amarasekara, Director of Economic Research and the Chairman of the Research Advisory Panel, Mr K R D Koswatte, Mrs N S Hemachandra and Mr S M Rajakaruna of the Central Bank of Sri Lanka for their support and encouragement. The views expressed in this paper are those of the author and do not necessarily reflect those of the Central Bank of Sri Lanka. Corresponding email: kesavan@cbsl.1k
} 


\section{Introduction}

In the recent years, the growth effects of size and the nature of public expenditure have emerged as a major issue in economies that are in transition. Public expenditures are less flexible than fiscal revenues, but much more sensitive with regard to business cycles and policy decisions of the government. Government collects revenue through various taxes and allocates to several sectors of the economy to pursue number of objectives. However, allocation of such expenditures is directly and indirectly associated with growth in the respective economies (Barro, 1990; Tanzi and Zee, 1997; Bayraktar, et al. 2015). For instance, the supply of social and physical infrastructure, rule of law, and protection of property rights are assumed to be conducive for growth (Ram, 1986). Over the period, public expenditure policies in both advanced and emerging economies mainly aimed at promoting sustained and equitable economic growth. However, literature highlights growth effects of public expenditure are positive when the size of government is small, but it may become negative as the size gets larger (Grossman and Helpman, 1991).

In the context of surging public expenditure and crumbling output growth, the growth effects of public expenditure have provoked an extensive discussion in the economic and political arenas of Sri Lanka. Since 1977, both public expenditure and its composition have changed intensely and largely been accompanied by expansion in size of successive governments (Figure A2 in Appendix). However, on the empirical front, the existing studies for Sri Lanka (Herath, 2010; Lahirushan, and Gunasekara, 2015; Dilrukshini, 2004) have focused on either the growth effects of total public expenditure or the specific individual expenditure. To the best of our knowledge, a few studies have examined the growth effects of public expenditure at disaggregated levels (Kesavarajah, M and Ravinthirakumaran, N, 2011). This study, therefore, attempts to fill an existing gap in the literature in light of more recent evidence.

The present study departs from existing literature in four key aspects. First, this study uses a time series dataset covering the entire post-liberalization period from 1977 to 2016 and places special focus on the presence of structural breaks in both public expenditure and economic growth series ${ }^{1}$. Secondly, public expenditure will be used as opposed to government consumption expenditure. Thirdly, this study will consider public expenditure at a disaggregated level to isolate productive elements of public expenditure from total. Finally, the analytical approach adopted in this study will be different from previous studies.

Although it is difficult to determine whether Sri Lanka has reached its optimal size of public expenditure, understanding the growth effects of public expenditure would clearly link policy contribution made by public expenditure in spurring growth. Therefore, the main research

\footnotetext{
${ }^{1}$ Sri Lankan economy was liberalised in 1977. The study period covered in this study contains two important break periods. First, the civil war started in 1983 ended in 2009. And second, the global financial crisis which emerged in 2008.
} 
question this study attempts to address is: have growing public expenditure really helped in stimulating economic growth in Sri Lanka. In addressing this question, a fundamental issue then is what components of public expenditure might be conducive or detrimental to economic growth in Sri Lanka? This study aims to provide fresh empirical insights for these research questions. Given the research questions, the primary objective of this study is to examine the growth effects of components of public expenditure in Sri Lanka. In this study, public expenditure on education, health, defense, agriculture and transport and communication are considered. These expenditure items are selected based on their share in total expenditure.

The rest of this paper is structured as follows. Section two briefly reviews theoretical and empirical literature relating to the relationship between public expenditure and economic growth. Section three highlights the data, econometric models and analytical framework adopted in this study. Section four offers quantitative insights on growth effects of both total and components of public expenditure. Final section summarizes major findings of the study, recommends appropriate policy responses, and suggests avenues for further research.

\section{Literature review}

\subsection{Theoretical review}

There are three main theories, namely Wagner's law, Keynesian growth theory and endogenous growth theory, which discuss theoretical relationships between public expenditure and economic growth. According to Wagner's law, public expenditure is an endogenous factor driven by growth of national income. It further states that economic activities undertaken by the government upsurges compared to the private sector during economic development (Wagner, 1883). In contrast, Keynesian growth theory (1936) considers public expenditure as an important exogenous variable in determining growth. It argues, given the assumption of price rigidity and possibility of excess capacity, expansion in fiscal policy stimulates growth through growing aggregate demand, which affects technical progress. Although both theories focus on short-run phenomenon of public expenditure, the causality between public expenditure and growth highlighted by these theories is different. According to Keynesian growth theory, causality runs from public expenditure to growth. Wagner's law presents the opposite conclusion. However, several studies including Devarajan, et al. (1996), Afonso and Furceri (2008) and Bose et al. (2007) highlight that the nexus between public expenditure and growth depends on the nature of the expenditure.

The endogenous growth theory highlights important factors that contribute to cross-country differences in both per capita income and growth rates. These factors comprise, investment in human capital (Lucas, 1988), knowledge spillovers, and investment in physical infrastructure. This theory argues that government's policies, including fiscal policy, can 
affects long-run growth. Although these theories highlight that public expenditure affects growth in several channels, empirically, however, each channel leads to varied conclusions.

\subsection{Empirical evidence}

Beyond theoretical outpourings, several empirical studies have investigated growth effects of public expenditure in both developed and developing economies. However, findings of these studies have brought inconclusive results. Some studies show that public expenditure has positive impacts on growth while others show detrimental impacts. Studies have also found neutral growth effects of public expenditure. Differences in outcome could be largely due to the nature of data and differences in econometric techniques.

A study conducted by Barro (1990) integrating both developed and developing economies for the period 1960 to 1985 shows that the nexus between public expenditure and growth is weak. Komain and Brahmasrene (2007) focusing on Thailand find a significant positive impact of public expenditure on growth. They also highlight that a unidirectional causality goes from public expenditure to growth. Using cross section data for 71 countries, Cooray (2009) shows that the growth effects of both government size and quality of governance are positive. Castles and Dowrick (1990) use composition of public expenditure and find that social transfers and education expenditure have a positive impact on economic growth. A similar study was conducted by Ranjan and Sharma (2008) for the case of Indian economy and found growth effects of public expenditure to be positive and significant during the period 1950 to 2007.

Tanzi and Zee, (1997) find that public expenditure on infrastructure, human capital, science and technology influences positively on economic growth. Avila and Strauch (2003) show that the expenditure side of budget consistently affected growth in 15 member countries in European Union for the period 1960 to 2001. The study argues that investment expenditure had positive impacts on growth but expenditure on consumption and transfer payments had significant negative impacts on growth. However, Levine and Renelt (1992) show that growth effects of public expenditure are insignificant. Similarly, Devarajan, et al. (1996) investigate growth effects of various types of public expenditure and highlighted components of public expenditure matters for growth.

Although many studies establish positive growth effects of public expenditure, studies also showed opposite results. A study conducted by Folster and Henrekson (2001) for Organization for Economic Cooperation and Development (OECD) countries highlight negative growth effects of public expenditure. They show countries experienced with higher public expenditure registered lower output growth compared with countries registered low public expenditure. Ramayandi (2003) found adverse impacts of increased public expenditure on growth in Indonesia. Conducting a research for a sample of 96 countries, 
Landau (1983) concluded expenditure on education and defense sectors has a weak impact on growth. He also confirmed that growth effects of total expenditure are negative.

Few studies have examined growth effects of public expenditure in Sri Lanka and results are inconclusive. Herath (2010) covering the period 1959 to 2003 found positive and significant impacts of public expenditure on economic growth. He also confirms positive growth effects of openness. Similar results have been established by Lahirushan and Gunasekara (2015) while confirming bidirectional causality between public expenditure and growth. Meanwhile, Jayawickrame (2004) stresses reduction in government consumption expenditure, transfer payments and investment expenditure, which have adverse impacts on growth. However, Dilrukshini (2004) shows that there is no empirical evidence in support of either Wagner's Law or the Keynesian hypothesis in Sri Lanka.

\section{Data, econometric models and analytical framework}

\subsection{Data}

This study uses time series annual data for the period 1977 to 2016. The data on fiscal variables are mainly based on annual reports of the Central Bank of Sri Lanka (CBSL). Data for other variables have been extracted from three different sources. Growth rates of GDP and gross fixed capital formation are mainly drawn from World Development Indicators. Further, growth rates of population and inflation are drawn from various publications of the Department of Census and Statistics (DCS) of Sri Lanka. The data on human capital variables are drawn from Barro and Lee (2000) data set. Detailed explanation on variables and their sources are given in Table A1 in Appendix.

\subsection{Econometric models}

The analysis of this study will be based on the standard growth regression model. The standard growth regression model, which follows seminal contribution of Barro (1990), has been widely used in empirical research on economic growth. This model is based on a conditional convergence equation that relates output growth to initial levels of income, investment, human capital and population growth. However, to achieve the main objective of the present study, we augment standard growth regression model with both fiscal and non-fiscal variables. Accordingly, the basic empirical model is specified as follows.

$$
G R_{t}=\beta_{0}+\sum_{j=1}^{p} \beta_{j} X_{t}+\sum_{j=1}^{q} \beta_{j} Y_{t}+\sum_{j=1}^{r} \beta_{j} Z_{t}+\varepsilon_{t}
$$


Where, $\mathrm{t}$ is the year index, GR is the growth rate of real GDP, $\beta_{0}$ and $\beta_{\mathrm{j}}$ are coefficients in regression model. $\varepsilon_{t}$ is the error term assumed to be white noise process. Growth rate of real GDP is dependent variable and explanatory variables are classified into three groups: $\mathrm{X}$, $\mathrm{Y}$ and Z. Group X consists of conditioning variables that are commonly appears in growth regression model, while group $\mathrm{Y}$ includes non-fiscal control variables that are generally included in empirical literature on economic growth. Fiscal variables that we are interested in this study are included in group Z.

Consistent with advocates of growth theory, we include gross investment, growth rate of population and human capital as conditioning variables. Although inclusion of different control variables results to different outcomes, the selections of control variables in this study are based on growth literature. As many countries registered higher growth consistent with export-led strategies, we include trade openness as the control variable. Following Easterly and Rebelo (1993), we include broad money and inflation to capture growth effects of monetary policy and macroeconomic instability. Further, lagged value of economic growth is included to capture growth inertia factors. We also introduce a dummy variable to examine the impacts of civil war on growth.

As Sri Lanka is confronted with fiscal constraints over the periods, we considered government budget constraints to eliminate coefficient bias resulting from their omission (Bose et al. 2007). Accordingly, we include public expenditures, tax revenues and fiscal balance to growth regression model. We also exclude some expenditure items to avoid any multicollinearity problem. As there is a time lag between the execution of public expenditure and its propagation on economy, we consider lagged value of public expenditure in the model.

Since we aim to examine growth effects of both total and components of public expenditure, we first estimate growth effects of total public expenditure as specified in equation 2 and then we jointly include five components of public expenditure as given in equation 3 to isolate productive elements of public expenditure from total.

$$
\begin{gathered}
G R_{t}=\beta_{0}+\sum_{j=1}^{p} \beta_{j} X_{t}+\sum_{j=1}^{p} \beta_{j} Y_{t}+\beta_{1} E X P_{t}+\beta_{3} T R_{t}+\beta_{4} F B_{t}+\beta_{5} G R_{t-1}+ \\
\beta_{6} D w r_{t}+\varepsilon_{t} \\
G R_{t}=\beta_{0}+\sum_{j=1}^{p} \beta_{j} X_{t}+\sum_{j=1}^{p} \beta_{j} Y_{t}+\beta_{1} E D U_{t}+\beta_{1} H E L_{t}+\beta_{1} T R C_{t}+\beta_{1} A G_{t}+ \\
\beta_{1} D E F_{t}+\beta_{3} T R_{t}+\beta_{4} F B_{t}+\beta_{5} G R_{t-1}+\beta_{6} D w a r_{t}+\varepsilon_{t}
\end{gathered}
$$




\subsection{Analytical framework}

The analysis of this study will be conducted in five stages. Given that our sample involves the period around the end of the civil war in 2009 and the emergence of global financial crisis in 2008, we will first investigate structural changes in both economic growth and public expenditure series. The global maximiser test introduced by Bai and Perron (2003) will be used to determine any structural breaks.

As many time series variables contain unit root, in the second stage, we will examine stationary properties of all the variables using Augmented Dickey Fuller (ADF), Phillips Perron (PP) and Kwiatkowski-Phillips-Schmidt-Shin (KPSS) tests. We will use Akaike Information Criteria (AIC) with default lag order for selecting order of augmentation in ADF regression. Further, default settings of Bartlett Kernel and Newey-West Bandwidth will be used for KPSS tests.

Although Engel-Granger (1987) and Johenson and Juselious (1990) methods are widely used to examine co-integration among variables, these techniques are not reliable for small sample size and may not provide co-integration even when all variables are integrated with order I(1) (Kremers at el, 1992). Therefore, in the third stage, we will use the Autoregressive Distributed Lag (ARDL) approach introduced by Pesaran and Pesaran (1997) to examine long-run dynamics among variables. This approach can be applied even when variables are $\mathrm{I}(0)$ or $\mathrm{I}(1)$ or mixture of both. It also considers adequate number of lags to capture data generating process. Given the scope of this study, the ARDL model is specified as follows.

$$
\begin{aligned}
& \Delta G R_{t}=\beta_{0}+\beta_{1} G R_{t-1}+\beta_{2} X_{t-1}+\beta_{3} Y_{t-1}+\beta_{4} Z_{t-1}+\sum_{j=1}^{p} \lambda_{j} \Delta G R_{t-j}+ \\
& \sum_{j=1}^{p} \Psi_{j} \Delta X_{t-j}+\sum_{j=1}^{p} \theta_{j} \Delta Y_{t-j}+\sum_{j=1}^{p} \Pi_{j} \Delta Z_{t-j}+\beta_{5} \operatorname{Dwar}_{t}+\varepsilon_{t}
\end{aligned}
$$

Equation 4 estimates $(p+1) k$ number of regressions to obtain optimal lag length for each variable in the model. Where, $\mathrm{p}$ is the optimal lag to be used and $\mathrm{k}$ is the number of variables. $\Delta$ is the first difference operator. As Schwarz Information Criteria (SIC) is widely known as parsimonious model and selects smallest possible lag length, we will use SIC to select optimal lag length in this study. If variables are found to be co-integrated, we will estimate ARDL Error Correction Model (ECM) to investigate short-run dynamics among variables. The error correction version of modified ARDL model is specified as follows. 


$$
\begin{aligned}
& \Delta G R_{t}=\sum_{h=1}^{p 1} \lambda_{h} \Delta G R_{t-h}+\sum_{j=1}^{p 2} \Psi_{j} \Delta X_{t-j}+\sum_{s=1}^{p 3} \theta_{s} \Delta Y_{t-s}+\sum_{i=1}^{p 4} \Pi_{i} \Delta Z_{t-i}+ \\
& \gamma E C_{t-1}+\varepsilon_{t} \\
& \Delta G R_{t}=\sum_{h=1}^{p 1} \lambda_{h} \Delta G R_{t-h}+\sum_{j=1}^{p 2} \Psi_{j} \Delta X_{t-j}+\sum_{s=1}^{p 3} \theta_{s} \Delta Y_{t-s}+\sum_{i=1}^{p 4} \Pi_{i} \Delta Z_{t-i}+ \\
& \gamma E C_{t-1}+\varepsilon_{t}
\end{aligned}
$$

The coefficient $(\gamma)$ of EC, which shows the speed of adjustment on a yearly basis to longrun equilibrium after a short-run deviation, should be negative and significant. Finally, we will conduct appropriate diagnostic and stability tests to ensure goodness of fit of estimated ARDL model. The stability testing will be conducted using both Cumulative Sum (CUSUM) and Cumulative Sum of Squares (CUSUMSQ) methods suggested by Pesaran and Pesaran (1997).

\section{Results and discussion}

\subsection{Testing for structural breaks}

The structural break tests based on global maximiser test for both public expenditure and economic growth confirmed absence of any structural break in both series (see Table B1 and B2 in Appendix B). Therefore, we proceed with the next step to examine order of integration of the variables.

\subsubsection{Unit root test}

It is noted that except the human capital variable, which exhibits an upward trend, all other variables do not exhibit a clear trend (see Figure A1 in Appendix A). Hence, we included only an 'intercept' component in ADF test. It is confirmed that twelve variables are stationary in levels (see Table 1). However, it is found that three variables are non-stationary since the null hypothesis of series being stationary cannot be rejected in both ADF and PP tests at 5 percent level of significance. However, all three tests confirmed that the remaining variables are integrated with order one. Since variables used in this study have a mixed order of integration, we proceed with estimating ARDL models for co-integration testing. 
Table 1: Unit root tests - levels and first difference

\begin{tabular}{|c|c|c|c|c|c|c|c|}
\hline \multirow[t]{2}{*}{ Variables } & \multicolumn{2}{|c|}{ ADF Test } & \multicolumn{2}{|c|}{ PP Test } & \multicolumn{2}{|c|}{ KPSS Test } & \multirow{2}{*}{$\begin{array}{c}\text { Order of } \\
\text { Integration }\end{array}$} \\
\hline & Level & $\begin{array}{c}\text { First } \\
\text { Difference }\end{array}$ & Level & $\begin{array}{c}\text { First } \\
\text { Difference }\end{array}$ & Level & $\begin{array}{c}\text { First } \\
\text { Difference }\end{array}$ & \\
\hline gr & $-4.7984 * * *$ & $-9.1672 * * *$ & $-4.7945 * * *$ & $-25.6584 * * *$ & 0.0871 & $0.5000^{* *}$ & $\mathrm{I}(0)$ \\
\hline \multicolumn{8}{|c|}{ X Variables } \\
\hline inv & $-3.7531 * *$ & $-5.0329 * * *$ & $-3.9757 * *$ & $-5.7959 * * *$ & 0.0770 & $0.1242^{* *}$ & $\mathrm{I}(0)$ \\
\hline $\mathrm{pg}$ & $-5.6943 * * *$ & $-6.7098^{* * *}$ & $-6.7001 * * *$ & $-27.1822^{* * *}$ & $0.1529 * *$ & $0.5000^{* *}$ & $\mathrm{I}(0)$ \\
\hline hucp & -1.7919 & $-6.7334 * * *$ & -1.6342 & $-7.5965^{* * *}$ & $0.1663^{* *}$ & 0.2490 & $\mathrm{I}(1)$ \\
\hline \multicolumn{8}{|c|}{ Y Variables } \\
\hline opp & $-3.2233 * * *$ & $-8.0797 * * *$ & $-3.4230 * *$ & $-8.3629 * * *$ & $0.1718^{* *}$ & 0.2818 & $\mathrm{I}(0)$ \\
\hline $\mathrm{m} 2$ & -1.9517 & $-6.1518^{* * *}$ & -2.4967 & $-6.1777 * * *$ & 0.0853 & $0.1337^{* *}$ & $\mathrm{I}(1)$ \\
\hline $\inf$ & $-5.6249 * * *$ & $-6.0579 * * *$ & $-5.6258 * * *$ & $-17.6133^{* * *}$ & 0.0629 & $0.2825^{* *}$ & $\mathrm{I}(0)$ \\
\hline \multicolumn{8}{|c|}{ Z Variables } \\
\hline pexp & $-5.9531 * * *$ & $-6.5428 * * *$ & - & $-29.0965^{* * *}$ & $0.5000^{* *}$ & 0.2721 & $\mathrm{I}(0)$ \\
\hline $\mathrm{fb}$ & $-6.4543 * * *$ & -10.8657 & $\begin{array}{l}10.3866 * * * \\
-6.3894 * * *\end{array}$ & $-13.3118^{*}$ & 0.0659 & $0.1223^{* *}$ & $\mathrm{I}(0)$ \\
\hline trev & $-3.7997 * * *$ & - & $-5.4604 * * *$ & $-10.7585^{*}$ & $0.1202^{* * *}$ & 0.5000 & $\mathrm{I}(0)$ \\
\hline edu & $-3.2261 *$ & $\begin{array}{l}10.3300^{* * *} \\
-7.7934 * * *\end{array}$ & $-3.2168 * * *$ & $-8.2004 * * *$ & $0.1552 * *$ & 0.0672 & $\mathrm{I}(0)$ \\
\hline hth & $-3.8563^{* *}$ & $-7.1914 * * *$ & $-3.9318^{* *}$ & $-10.3078^{* * *}$ & 0.0608 & $0.6894 * *$ & $\mathrm{I}(0)$ \\
\hline $\operatorname{trc}$ & $-3.7958^{* * *}$ & $-9.3847 * * *$ & $-3.7665^{* * *}$ & $-9.8155^{* * *}$ & 0.0919 & $0.1669 * *$ & $\mathrm{I}(0)$ \\
\hline agr & $-6.8661 * * *$ & $-3.5260 * *$ & -2.9376 & $-7.5798^{* * *}$ & $0.1793^{* *}$ & 0.0613 & $\mathrm{I}(0)$ \\
\hline def & -1.5893 & $-6.3729 * * *$ & -1.4553 & $-6.4137 * * *$ & $0.1839 * *$ & 0.2627 & $\mathrm{I}(1)$ \\
\hline
\end{tabular}

Notes: $*$ indicates significance at $1 \%, * *$ indicates significance at $5 \%, * * *$ indicates significance at $10 \%$.

Source: Author's Estimation

\subsection{Estimation of ARDL models}

\subsubsection{ARDL model for growth effects of total public expenditure}

We estimated 20 ARDL models to examine growth effects of total public expenditure. The graphical representations of these 20 models are given in Figure 1. Based on the SIC, the ARDL model (1 $\left.\begin{array}{lllllllll}0 & 1 & 0 & 1 & 1 & 0 & 0 & 1 & 1\end{array}\right)$ was selected as the best model among them. Further, we conducted a stability test for estimated ARDL model $\left(\begin{array}{llllllllll}1 & 0 & 1 & 0 & 1 & 1 & 0 & 0 & 1 & 1\end{array}\right)$. Since both CUSUM and CUSUMSQ statistics prevailed within the critical bounds of 5 percent level of significance, the null hypothesis of estimated coefficients of ARDL model is stable cannot be rejected (see Figure 2 and 3). This confirms that estimated ARDL model is stable. 
Figure 1: Model selection summary - Schwarz information criteria (top 20 models)

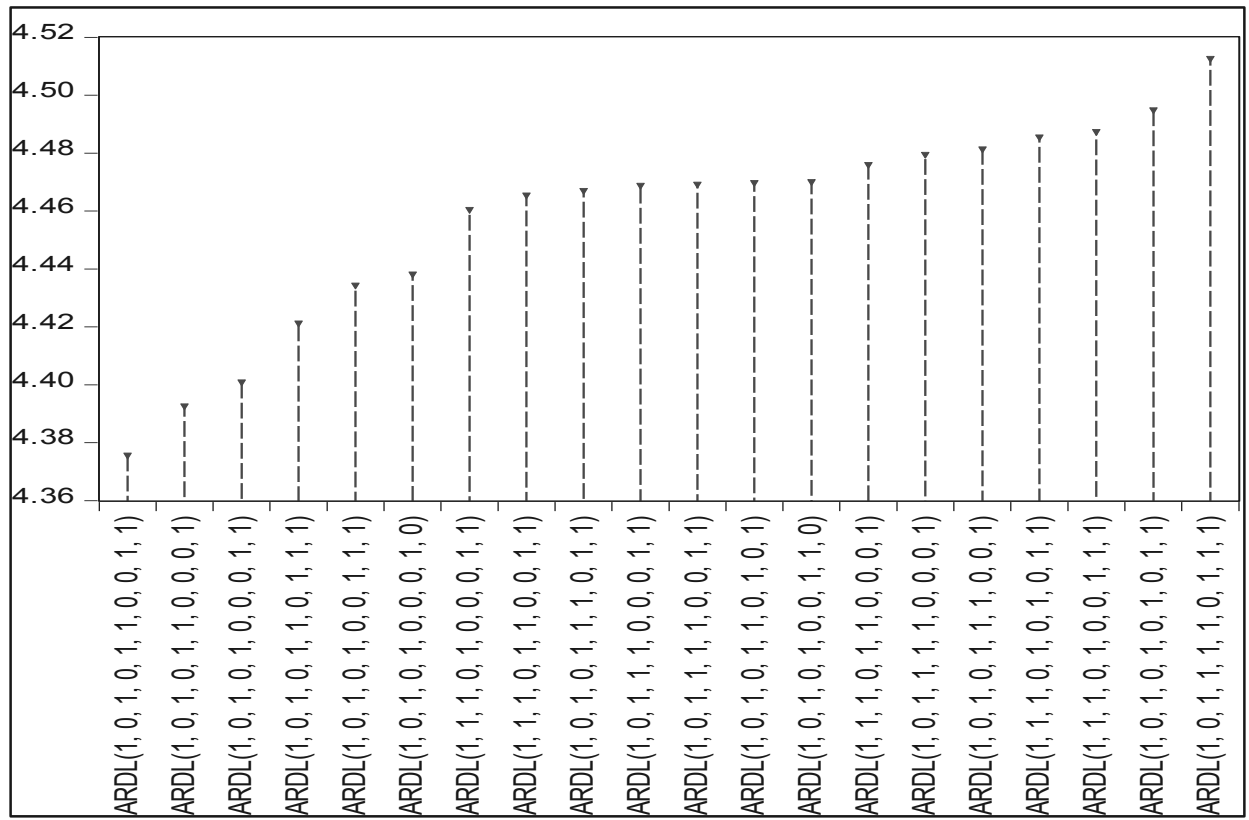

Note: The ordering of the variables is GR, PEXP, M2, OPP, INF, FB, TREV, HUCP, INV, PG.

Detailed descriptions of the variables are given in Appendix Table A1.

Figure 2: CUSUM test

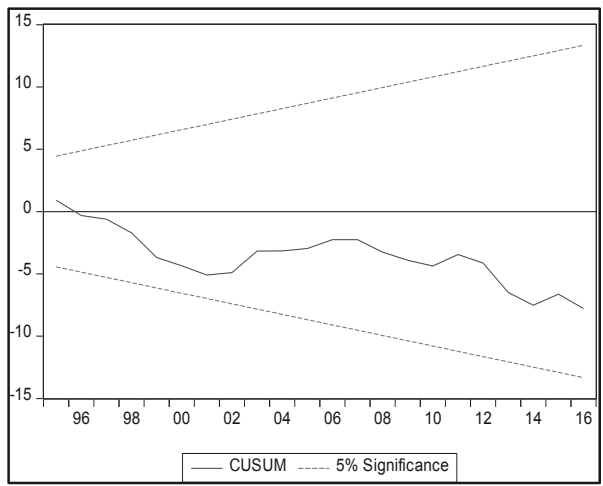

Source: Author's Estimation
Figure 3: CUSUM of square test

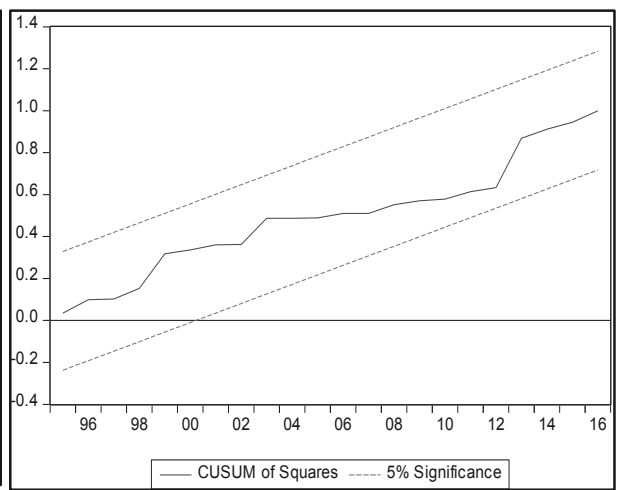


As estimated ARDL model is stable, we conducted ARDL-Bounds test to identify cointegration among variables in the model. The results of Bounds test are presented in Table 3. As calculated F-statistic is higher than upper bound critical values, the null hypothesis of no long-run (equilibrating) relationship can be rejected in all three significance level. This confirms the existence of a long-run relationship irrespective of order of integration of variables.

Table 3: ARDL bound tests for long-run relationship

\begin{tabular}{|c|c|c|c|c|c|c|c|}
\hline Test Statistic & Value & & $\begin{array}{l}\text { Oower } \\
\text { totic: }\end{array}$ & & & pper B & \\
\hline \multirow{2}{*}{ F-Statistic } & \multirow{2}{*}{6.78265} & \multicolumn{3}{|c|}{ Significance Level } & \multicolumn{3}{|c|}{ Significance Level } \\
\hline & & $10 \%$ & $5 \%$ & $1 \%$ & $10 \%$ & $5 \%$ & $1 \%$ \\
\hline $\mathrm{K}$ & 9 & 1.8 & 2.04 & 2.5 & 2.8 & 2.08 & 3.68 \\
\hline
\end{tabular}

Source: Author's Estimation

Note: The critical value bounds are computed by stochastic simulations using 1000 replications. K represents the number of variables that we have included in the ARDL bound test.

\subsubsection{ARDL model for growth effects of components of public expenditure}

We estimated 20 ARDL models based on SIC to examine growth effects of components of public expenditure (see Figure 4). However, we selected ARDL (1, 0, 0, 1, 1, 0, 0, 1, 1, 1, 0, $1,0,1)$ model as the best model among all other models. Moreover, the stability of the estimated ARDL model was investigated using both CUSUM and CUSUMSQ methods. Since both CUSUM and CUSUMSQ statistics prevailed within the critical bounds of 5 percent level of significance, the null hypothesis of estimated coefficients of ARDL model is stable cannot be rejected. This confirms that the estimated ARDL model is stable.

As estimated ARDL model is stable, we applied ARDL Bounds tests to examine the longrun relationship among variables. Accordingly, it is found that the F-statistic value of 10.48238 exceeds the critical value of upper bounds in all three significance levels (see Table 4). Therefore, the null hypothesis of no long-run relationship can be rejected in all three significance levels and it can be concluded that all the variables move together in the longrun irrespective of their order of integration. 
Figure 4: Model selection summary - Schwarz criteria (top 20 models)

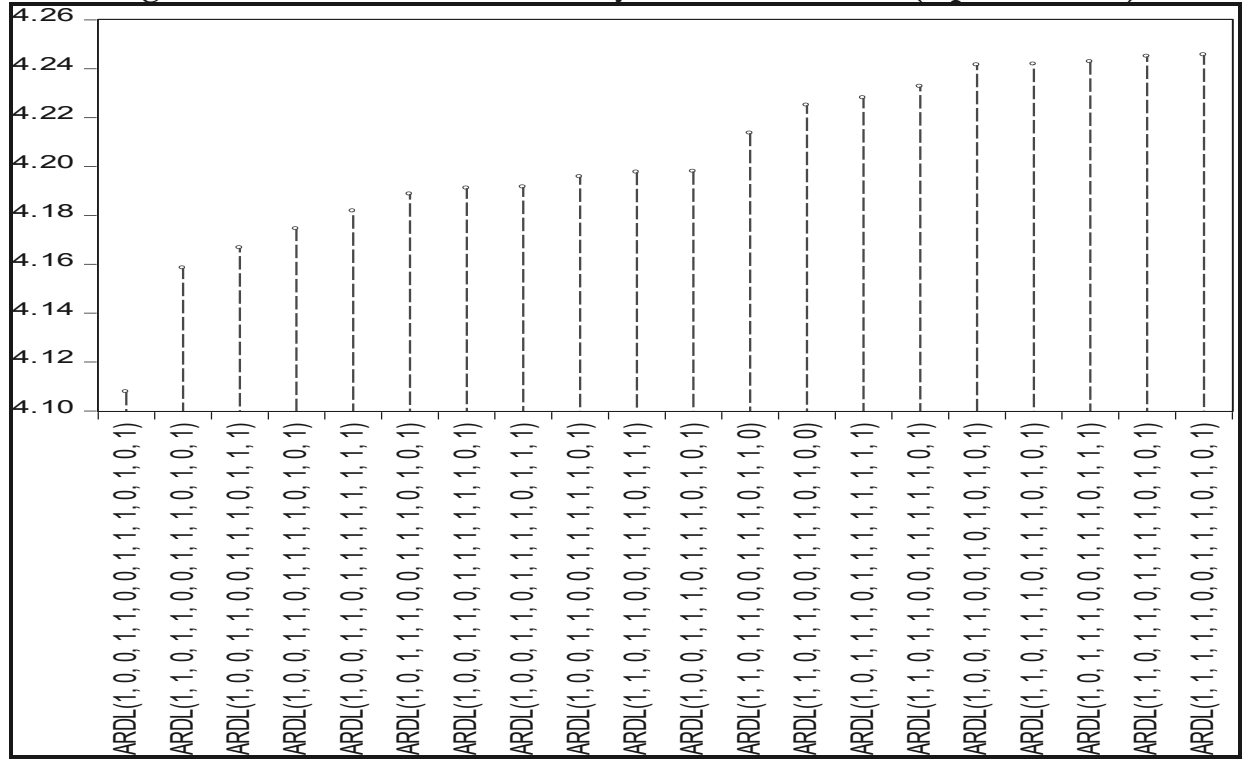

Note: The ordering of the variables is GR, PEXP, M2, OPP, INF, FB, TREV, HUCP, INV, PG.

Source: Author's Calculation

Figure 5: CUSUM test

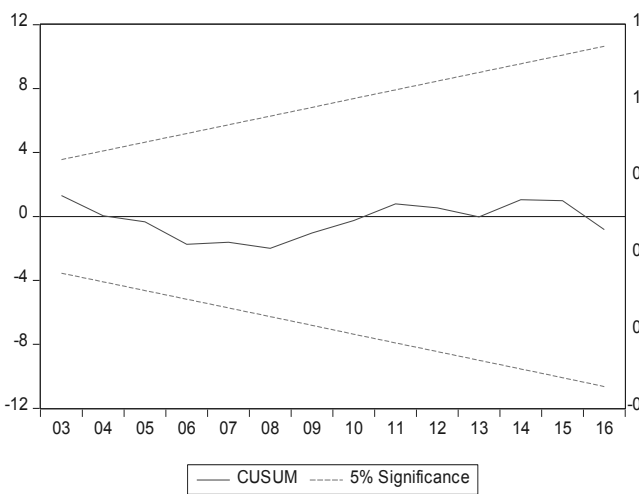

Source: Author's Estimation
Figure 6: CUSUM of squares test

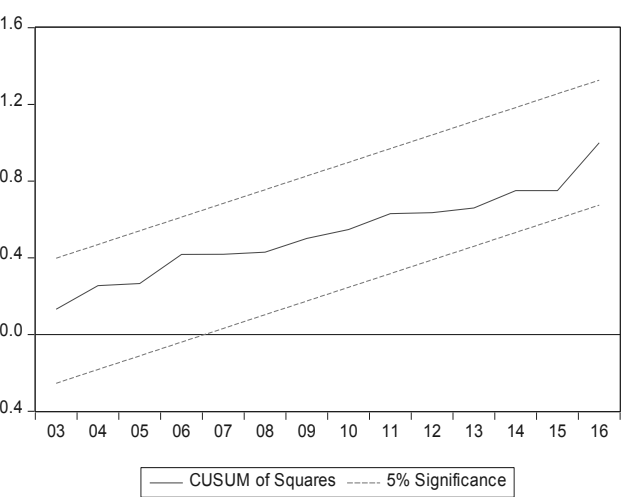

_ CUSUM of Squares ---- $5 \%$ Significance 
Table 4: ARDL bounds tests for long-run relationship

\begin{tabular}{|c|c|c|c|c|c|c|c|}
\hline \multirow{4}{*}{$\begin{array}{c}\begin{array}{c}\text { Test } \\
\text { Statistic }\end{array} \\
\text { F-Statistic }\end{array}$} & \multirow{4}{*}{$\begin{array}{c}\text { Value } \\
10.48238\end{array}$} & \multicolumn{3}{|c|}{$\mathrm{I}(0)$ : Lower Bound } & \multicolumn{3}{|c|}{ I(1): Upper Bound } \\
\hline & & \multicolumn{6}{|c|}{ Asymptotic: $\mathrm{n}=1000$} \\
\hline & & \multicolumn{3}{|c|}{ Significance Level } & \multicolumn{3}{|c|}{ Significance Level } \\
\hline & & $10 \%$ & $5 \%$ & $1 \%$ & $10 \%$ & $5 \%$ & $1 \%$ \\
\hline $\mathrm{K}$ & 13 & 1.76 & 1.98 & 2.41 & 2.77 & 3.04 & 3.61 \\
\hline
\end{tabular}

\subsection{The long-run impacts of public expenditure on economic growth}

\subsubsection{Total public expenditure}

As estimated models in section 4.2.1 and 4.2.2 established a co-integration among variables, in the next step, we proceed with estimating long-run coefficients using respective ARDL specifications in two different settings. The first set of estimations, which includes total public expenditure along with other control variables, is presented in the second column of Table 5. The second set of estimation, which includes components of public expenditure, is given in the last column of Table 5 .

As per model 1, total public expenditure has negative and significant impacts on growth. Holding other variables of the model constant, a one percent increase in public expenditure as a percentage of GDP is associated with approximately 0.18 percent decrease in long-term growth. This result is consistent with previous studies (Devarajan et al. 1996; Folster and Henrekson 2001), which argue that public expenditure has negative impacts on growth owing to inefficient and unproductive nature of such investments. However, the result contradicts with a previous study conducted by Herath (2010) who found positive growth effects of public expenditure for Sri Lanka. This conflicting result could be due to the inclusion of most recent data that captures recent changes in the economic structure and the usage of advanced econometrics techniques. However, given the increased public expenditure, examining the growth effects of public expenditure at disaggregated level is imperative for Sri Lanka. Therefore, a detailed analysis is conducted in the subsequent section. 
Table 5: Estimated long-run coefficients of ARDL model with budget constraint

\begin{tabular}{|c|c|c|}
\hline \multicolumn{3}{|c|}{ Dependent Variable: Growth rates of real GDP } \\
\hline Variable & $\begin{array}{l}\text { Results with Total Public } \\
\text { Expenditure } \\
\text { (Model 1) } \\
\text { ARDL Model: } \\
(1,0,1,0,1,1,0,0,1,1)\end{array}$ & $\begin{array}{c}\text { Results with Components of } \\
\text { Total Public Expenditure } \\
\text { (Model 2) } \\
\text { ARDL Model: } \\
(1,0,0,1,1,0,0,1,1,1,0 \\
1,0,1)\end{array}$ \\
\hline X Variables & & \\
\hline Investment $(\%$ of GDP $)$ & $\begin{array}{c}0.5863 * * * \\
(4.9316)\end{array}$ & $\begin{array}{l}0.4264^{* *} \\
(2.1360)\end{array}$ \\
\hline Population Growth Rate & $\begin{array}{c}0.3783 \\
(0.3021)\end{array}$ & $\begin{array}{c}0.7487 \\
(1.1874)\end{array}$ \\
\hline Human Capital & $\begin{array}{l}0.0505 \\
(1.0565)\end{array}$ & $\begin{array}{l}0.1118^{* * *} \\
(2.9504)\end{array}$ \\
\hline Y Variables & & \\
\hline Trade Openness (( $\%$ of GDP) & $\begin{array}{l}6.2649 \\
(1.6135)\end{array}$ & $\begin{array}{c}0.2680 \\
(0.6501)\end{array}$ \\
\hline $\begin{array}{c}\text { Money Supply (M2) } \\
\text { (\% of GDP) }\end{array}$ & 0.1447 & 0.0406 \\
\hline & $(0.8153)$ & $(0.3222)$ \\
\hline Inflation Rate & $\begin{array}{c}0.1008 \\
(1.3230)\end{array}$ & $\begin{array}{c}0.0314 \\
(1.5883)\end{array}$ \\
\hline Growth Rates of GDP (-1) & $\begin{array}{c}-0.9485^{* * *} \\
(-5.6317)\end{array}$ & $\begin{array}{c}-1.0527 * * * \\
(-8.1275)\end{array}$ \\
\hline DWAR & $\begin{array}{l}-2.9306 * * * \\
(-2.6083)\end{array}$ & $\begin{array}{l}-0.7769 \\
(-0.7975)\end{array}$ \\
\hline $\begin{array}{c}\text { Z Variables } \\
\text { Total Expenditure }(-1) \\
(\% \text { of GDP) }\end{array}$ & $\begin{array}{c}-0.1797^{* * *} \\
(-3.6259)\end{array}$ & \\
\hline Tax Revenue ( $\%$ of GDP) & $\begin{array}{l}-0.4571 \\
(-0.7487)\end{array}$ & $\begin{array}{c}-0.7353 * * * \\
(-2.6989)\end{array}$ \\
\hline $\begin{array}{l}\text { Fiscal Balance } \\
(\% \text { of GDP) }\end{array}$ & $\begin{array}{l}0.2204^{* *} \\
(2.3135)\end{array}$ & $\begin{array}{l}0.2617 \\
(1.4411)\end{array}$ \\
\hline $\begin{array}{l}\text { Education Expenditure }(-1) \\
\qquad(\% \text { of GDP) }\end{array}$ & & $\begin{array}{c}5.8003 * * * \\
(3.3396)\end{array}$ \\
\hline $\begin{array}{l}\text { Health Expenditure }(-1) \\
\text { (\% of GDP) }\end{array}$ & & 0.7249 \\
\hline $\begin{array}{l}\text { Transport and Communication } \\
\text { Expenditure }(-1)(\% \text { of GDP) }\end{array}$ & & $\begin{array}{l}(0.3695) \\
0.7831^{*} \\
(1.9242)\end{array}$ \\
\hline $\begin{array}{l}\text { Agriculture Expenditure }(-1) \\
(\% \text { of GDP) }\end{array}$ & & $\begin{array}{c}1.2721 * * * \\
(3.3216)\end{array}$ \\
\hline $\begin{array}{l}\text { Defense Expenditure }(-1) \\
(\% \text { of GDP })\end{array}$ & & $\begin{array}{l}-0.2545 \\
(-0.6548)\end{array}$ \\
\hline Constant & $\begin{array}{l}-10.1814 \\
(-0.7963)\end{array}$ & $\begin{array}{l}-14.8284 \\
(-1.5168)\end{array}$ \\
\hline No. of Observations & 40 & 40 \\
\hline
\end{tabular}

Notes: ***indicates significance at $1 \%$, ** indicates significance at $5 \%$ and $*$ indicates significance at $10 \%$ levels. t-statistics are given in parenthesis. (-1) indicates variables lagged one period. Source: Author's Estimation 


\subsubsection{Components of public expenditure}

As evident from model 2, growth effects of total expenditure on education are found to be positive and statistically significant (see Table 5). The magnitude of growth effects of education expenditure is substantial. This result is consistent with new growth literature which strongly validates the argument of education expenditure as an essential factor in determining growth. Holding other variables constant, one percent increase in expenditure in education as a percentage of GDP is associated with an increase in average growth rate by 5.8 percent. Previous studies by Castles and Dowrick (1990) also established similar results. The positive impacts of education expenditure could be due to strong spill-over effects of investment in the education sector in raising the productivity of both human and physical capital. However, our results contradict with previous studies conducted by Barro and Sala-iMartin (1992), Landau (1983) and Devarajan et al.(1996) that established insignificant impacts of education expenditure.

Health expenditure is considered as an investment in human capital that influences growth. However, this study found that health expenditure has a positive but insignificant impact on growth. Our finding contradicts with previous studies of Cole and Neumayer (2006) who showed positive and significant growth effects of health expenditure. Inclusion of budget constraints, which is absent in previous studies, and is limited to only Sri Lankan economy could partly explain reasons for different outcomes. To our knowledge, studies on growth effects of health expenditure are almost non-existent in the literature on Sri Lanka and therefore this study provides fresh empirical evidence.

Meanwhile, this study found growth effects of transport and communication expenditure are positive and significant. The result is consistent with previous studies conducted by Fedderke et al. (2006), who confirmed positive impacts of infrastructure on growth in South Africa. The present study also stresses that expenditure on transport and communication sector is crucial for growth. Furthermore, this study clearly establishes positive and significant growth effects of agriculture expenditure. Therefore, allocating funds towards agriculture sector would not only enhance growth but could also improve the wellbeing of rural population. Meanwhile, coefficient on defence expenditure is negative but statistically insignificant. This is consistent with previous studies such as Landau (1983) and Deger and Smith (1983). The diversion of expenditure towards unproductive sectors including defense results in a reduction of public savings and investments and thereby undermines growth. Although this study found adverse impacts of defence expenditure, some positive impacts are also justified in literature (see Frederiksen and Looney, 1983; Ram, 1986).

Looking at other variables that are considered in this study, while model 1 does not provide any evidence on growth effects of tax revenue, model 2 highlights negative and significant effects. The negative impacts of tax revenue could be identified from different channels. Increased taxation discourages both domestic and international investment and thereby adversely affects long-term growth. It also adversely affects investment in human capital and 
entrepreneurial activities. However, investigating growth effects of components of tax revenue is beyond the scope of this study. The budget surplus has significant positive impacts on growth in both models. Holding other variables constant, one percent increase in fiscal surplus as a share of GDP is associated with an increase in annual growth rate by an average of 0.22 and 0.26 percent in model 1 and 2 respectively. This highlights that controlling fiscal deficit is vital to enhance long-term growth.

Looking at growth effects of non-fiscal variables, the study found that investment played a crucial role in stimulating growth, which is consistent with neoclassical growth theory. Several previous studies including a study by Levine and Renelt (1992) also acknowledge investment as important determinants of growth. Holding other variables constant, one percent increases in total investment as a percentage of GDP is associated with an increase in growth rate by 0.6 percent in model 1 and 0.4 percent in model 2 . This necessitates the creation of a conducive environment in Sri Lanka to attract both domestic and global investment. Human capital is found to have a positive impact on growth in both models though significance can be observed only in model 2. While inflation, population growth, money supply and trade openness accord well with theoretical predictions, they are turn out to be insignificant in both models. It is evident that growth can be accounted for by its own innovations. The study also confirmed that civil war had negatively affected growth in both models though the significance could be identified only in model 1.

\subsection{Estimation of ARDL Error Correction Model (ECM)}

As the Bounds test established a long-run co-integration among variables, we will use ECM of ARDL to estimate short-run dynamics among the variables. The error correction term is negative and significant in both models. This shows a high level of speed of adjustment to long-run equilibrium following a short-run shock (see Table 6). About 34.41 percent and 52.70 percent of disequilibrium from previous year's short-run shocks converges back to long-run equilibrium each year in model 1 and 2.

Although signs of short-run coefficients of total public expenditure are in line with Keynesian theoretical outpourings, its impact on growth is insignificant. It is found that total expenditure on education and agriculture, has a similar impact in the short-run too but with different magnitudes. However, the transport and communication expenditure that exhibited positive and significant impacts on long-run growth do not provide any evidence in the short-run. Growth effects of health expenditure is insignificant in the short-run as well. Similar to long-term results, growth effects of fiscal balance are positive though impact is significant only in model 1 . However, the degree of impacts is much lower in the short-run compared to the long-run. This result strengthens the argument in favour of rapidly implementing effective policies for deficit reduction in Sri Lanka. 
Table 6: ARDL Error Correction Model of the growth equation Dependent Variable: Growth rates of real GDP

\begin{tabular}{|c|c|c|}
\hline Variable & $\begin{array}{c}\text { Results with Total Public } \\
\text { Expenditure } \\
{[\text { ARDL }(1,0,1,0,1,1,0,0,1,1)]}\end{array}$ & $\begin{array}{l}\text { Results with Components of Total Public } \\
\text { Expenditure } \\
\text { [ARDL }(1,0,0,1,1,0,0,1,1,1,0,1,0,1)]\end{array}$ \\
\hline \multicolumn{3}{|l|}{ X Variables } \\
\hline $\mathrm{D}(\mathrm{INV})$ & $\begin{array}{c}0.3441 \text { *** } \\
(3.9959)\end{array}$ & $\begin{array}{c}0.5841 * * * \\
(5.6434)\end{array}$ \\
\hline $\mathrm{D}(\mathrm{PG})$ & $\begin{array}{c}0.3783 \\
(0.8623)\end{array}$ & $\begin{array}{c}0.0314 \\
(1.5883)\end{array}$ \\
\hline $\mathrm{D}$ (HUCP) & $\begin{array}{c}0.1039 \\
(1.2609)\end{array}$ & \\
\hline \multicolumn{3}{|l|}{ Y Variables } \\
\hline $\mathrm{D}(\mathrm{M} 2)$ & $\begin{array}{c}-0.6560 * * * \\
(5.3981)\end{array}$ & \\
\hline $\mathrm{D}(\mathrm{INF})$ & $\begin{array}{c}-0.0939 * * * \\
(-2.9265)\end{array}$ & $\begin{array}{c}-0.6632 * \\
(-1.9409)\end{array}$ \\
\hline WRDUM & $\begin{array}{c}-2.9306 * * * \\
(-8.2899)\end{array}$ & $\begin{array}{c}-7.7612^{* * *} \\
(-16.4002)\end{array}$ \\
\hline \multicolumn{3}{|l|}{ Z Variables } \\
\hline $\mathrm{D}(\operatorname{PEXP}(-1))$ & $\begin{array}{c}0.0020 \\
(0.0839)\end{array}$ & \\
\hline $\mathrm{D}(\mathrm{FB})$ & $\begin{array}{c}0.6889 * * * \\
(7.6513)\end{array}$ & $\begin{array}{c}0.5593 * * * \\
(10.5940)\end{array}$ \\
\hline $\mathrm{D}(\mathrm{EDU})$ & & $\begin{array}{c}3.7185^{* * * *} \\
(7.6721)\end{array}$ \\
\hline $\mathrm{D}(\mathrm{HTH})$ & & $\begin{array}{c}0.0049 \\
(0.0772)\end{array}$ \\
\hline $\mathrm{D}(\mathrm{AGR})$ & & $\begin{array}{c}0.2076 * * \\
(1.9636)\end{array}$ \\
\hline $\operatorname{ECM}(-1)$ & $\begin{array}{c}-0.3441 \text { *** } \\
(-3.9959)\end{array}$ & $\begin{array}{c}-0.5270^{* * *} \\
(-8.5970)\end{array}$ \\
\hline $\mathrm{R}$-squared & 0.8307 & 0.9274 \\
\hline Adj. R2 & 0.7989 & 0.9079 \\
\hline Durbin-Watson stat & 1.9792 & 2.04265 \\
\hline
\end{tabular}

Although signs of short-run coefficients of total public expenditure are in line with Keynesian theoretical outpourings, its impact on growth is insignificant. It is found that total expenditure on education and agriculture, has a similar impact in the short-run too but with different magnitudes. However, the transport and communication expenditure that exhibited positive and significant impacts on long-run growth do not provide any evidence in the short-run. Growth effects of health expenditure is insignificant in the short-run as well. Similar to long-term results, growth effects of fiscal balance are positive though impact is significant only in model 1. However, the degree of impacts is much lower in the short-run compared to the long-run. This result strengthens the argument in favour of rapidly implementing effective policies for deficit reduction in Sri Lanka. 
Although growth effects of inflation are insignificant in the long-run, they have a negative and significant impact in the short-run. The main policy message is that reducing inflation by 1 percent could raise growth by 0.66 percent. This provides strong evidence to support the view of low inflation to stimulate short-term growth. Moreover, investigating channels through which inflation affects growth is essential, but it is beyond the scope of this study. Growth effects of investment exhibit positive and significant results in both models, which is consistent with long-run results. Although long-run growth effects of money supply are consistent with theoretical prediction, the study shows that money supply has significantly affected growth in the short-run. It is also evident that the civil war undermined economic growth in the short-run as well. The short-run impacts of all other variables are insignificant though they had expected sign in both models.

\section{Conclusion}

This study provides new empirical understanding on growth effects of public expenditure at both aggregate and disaggregate levels for Sri Lanka considering the full implication of government budget constraints. The present study found that the growth effects of public expenditure vary at the disaggregated level. The growth effects of total expenditure on education and transport and communication were found to be positive and statistically significant, while health, agriculture and defense expenditure were found to be statistically insignificant. Looking at growth effects of non-fiscal variables, the study found that investment and human capital played a crucial role in stimulating growth in Sri Lanka. Given the positive and significant growth effects of expenditure on education, agriculture, transport and communication and negative but insignificant impacts of defense expenditure, this study suggests that reforming public expenditure in particular in favor of human capital development could stimulate long-term growth in Sri Lanka. As it is found that the tax revenue has adversely affected economic growth, the present study recommends that controlling possible detrimental impacts of taxation is vital to enhance growth. Given the positive growth effects of fiscal surplus, this study recommends that controlling fiscal deficit is paramount for sustainable growth. Based on the findings, this study proposes several lines of further investigation and some possible extensions to the research content of this study. As growth effects of public expenditure at disaggregated levels have shown mixed results, indepth studies focusing on disaggregated components even within these categories should be conducted. Although the present study showed valuable insights on growth effects of tax revenue, it is necessary to address potential growth implications arising from taxation at disaggregated levels. 


\section{References}

Afonso, A. and Furceri, D. 2008. "Government Size, Composition, Volatility and Economic Growth”. Working Paper Series 849, European Central Bank.

Avila, D. R. and Straugh, R. 2003. "Public Finances and Long-term Growth in Europe Evidence from a Panel Data Analysis", Working Paper Series. 246, European Central Banking.

Barro, R. 1990. "Government Spending in a Simple Model of Endogenous Growth". Journal of Political Economy, 98(1), 103-117.

Barro, R. and Sala-i-Martin, X. 1992. "Public Finance in Models of Economic Growth". Review of Economic Studies, 59, 645-661.

Bose, N., Haque, M. E. and Osborn, D. R. 2007. "Public Expenditure and Economic Growth: A Disaggregated Analysis for Developing Countries". The Manchester School. 75 (5): 533-556.

Castles, F. G. and Dowrick, S. 1990. "Impact of Government Spending Levels on Medium Term Economic Growth in the OECD, 1960-1985”. Journal of Theoretical Policies. 2, 173-204.

Central Bank of Sri Lanka, Annual Reports, Various Years.

Cole, M. A. and Neumayer, E. 2006. "The Impact of Poor Health on Total Factor Productivity". Journal of Development Studies, 42 (6), 918-38.

Cooray, A. 2009. "Government Expenditure, Governance and Economic Growth". Comparative Economic Studies, 51 (3), 401-418.

Deger, S. and Smith, R. 1983. "Military Expenditure and Growth in Less Developed Countries". Journal of Conflict Resolution, 27 (2), 335-353.

Devarajan, S., Swaroop, V. and Zou, H. F. 1996. "The Composition of Public Expenditure and Economic Growth". Journal of Monetary Economics. 37 (2), 313-344.

Dilrukshini, W. A. 2004. "Expenditure and Economic Growth in Sri Lanka: Co-integration Analysis and Causality Testing". Staff Studies, 34, 51-68.

Easterly, W. and Rebelo, S. 1993. "Fiscal Policy and Economic Growth: An Empirical Investigation". Journal of Monetary Economics, 32, 417-458.

Fedderke, J., Perkins, P. and Luiz, J. 2006. "Infrastructural Investment in Long-run Economic Growth: South Africa 1875- 2001”. World Development, 34(6), 1037-1059. 
Folster, S. and Henrekson, M. 2001. "Growth Effects of Government Expenditure and Taxation in rich Countries". European Journal of Political Economy. 45, 1501-1520.

Frederiksen, P. C. and Robert E. Looney. 1983. "Defense Expenditures and Economic Growth in Developing Countries: Some Further Evidence." Journal of Economic Development. 7, 113-26.

Grossman, G. and Helpman, E. 1991. Quality Ladders in the Theory of Growth. The Review of Economic Studies, 58(1), 43-61.

Herath, S. 2010. "Size of the Government and Economic Growth: An Empirical Study of Sri Lanka”. SRE Discussion Papers 2010/05, WU Vienna University of Economics and Business, Austria.

Jayawickrama, A. (2004). "Fiscal Policy Sustainability: Evidence from Sri Lanka". Sri Lanka Economic Journal 5(1): 55-74.

Johansen, S. and Juselius, K. 1990. "Maximum Likelihood and Inference on Cointegration with Applications to the Demand for Money". Oxford Bulletin of Economics and Statistics, 52(3), 169-210.

Kesavarajah, M., 2012. Wagner's Law in Sri Lanka: An Econometric Analysis, International Scholarly Research Network, Vol. Article ID 573826, pp. 1-9.

Kesavarajah, M., 2017. Growth Effects of Fiscal Deficits in Sri Lanka. Staff Studies, 47(1), pp.47-68.

Keynes, J. M. 1936. “General Theory of Employment, Interest and Money”. Harcourt, Brace and Co, New York, NY, USA.

Komain, J. and Brahmasrene, T. 2007. "Relationship between Government Expenditures and Economic Growth in Thailand." Journal of Economics and Economic Education Research. 8 (1), 93-102.

Kremers J.J.M., Ericsson N. R., and Dolado, J. J. 1992. "The Power of Cointegration Tests." Oxford Bulletin of Economics and Statistics, 54, 325-348.

Lahirushan, K. P. K. S. and Gunasekara, W. G. V. 2015. "The Impact of Government Expenditure on Economic Growth: A Study of Asian Countries", International Journal of Humanities and Social Sciences. 9(9). 3152-3160.

Landau, D. 1983. "Government Expenditure and Economic Growth: A Cross-Country Study". Southern Economic Journal, 49(3), 783-792. 
Levine, Ross, and David Renelt. 1992. "A Sensitivity Analysis of Cross-Country Growth Regressions," American Economic Review, LXXXII, 942-63.

Lucas, R. E. 1988. "On the Mechanics of Economic Development". Journal of Monetary Economics, 22, 3-42.

Pesaran, M. H, Pesaran, B. 1997. "Working with Microfit 4.0: Interactive Econometric Analysis", Oxford University Press: Oxford.

Ram, R. 1986. "Government size and Economic Growth: A New Framework and some evidence from Cross-section and Time-series data." American Economic Review, 76(1), 191-203.

Ramayandi, A. 2003. "Economic Growth and Government Size in Indonesia: Some Lessons for the Local Authorities". Working Papers in Economics and Development Studies, Padjadjaran University.

Ranjan, K. D. and Sharma, C. 2008. "Government Expenditure and Economic Growth: Evidence from India”. The ICFAI University Journal of Public Finance, 6 (3), 60-69.

Ravinthirakumaran, N. and Kesavarajah, M. (2011), "The Impact of Government Expenditure on Economic Growth in Sri Lanka: An Econometric Analysis" in Proceedings of the $8^{\text {th }}$ International Conference on Business Management, Faculty of Management Studies and Commerce, University of Sri Jayewardenepura, Nugegoda, Sri Lanka.

Tanzi, V. and H. Zee. 1997. "Fiscal Policy and Long-run Growth", IMF Staff Papers. 44 (2), 179-209.

Wagner, A. 1883. "Three Extracts on Public Finance”. in R.A. Musgrave and A.T. Peacock (eds) (1958), "Classics in the Theory of Public Finance", London: Macmillan.

World Bank. 2018. World Development Indicators. Washington, DC: World Bank. 


\section{Appendices}

\section{A.1 Information on data}

Figure A1: Behaviour of the variables
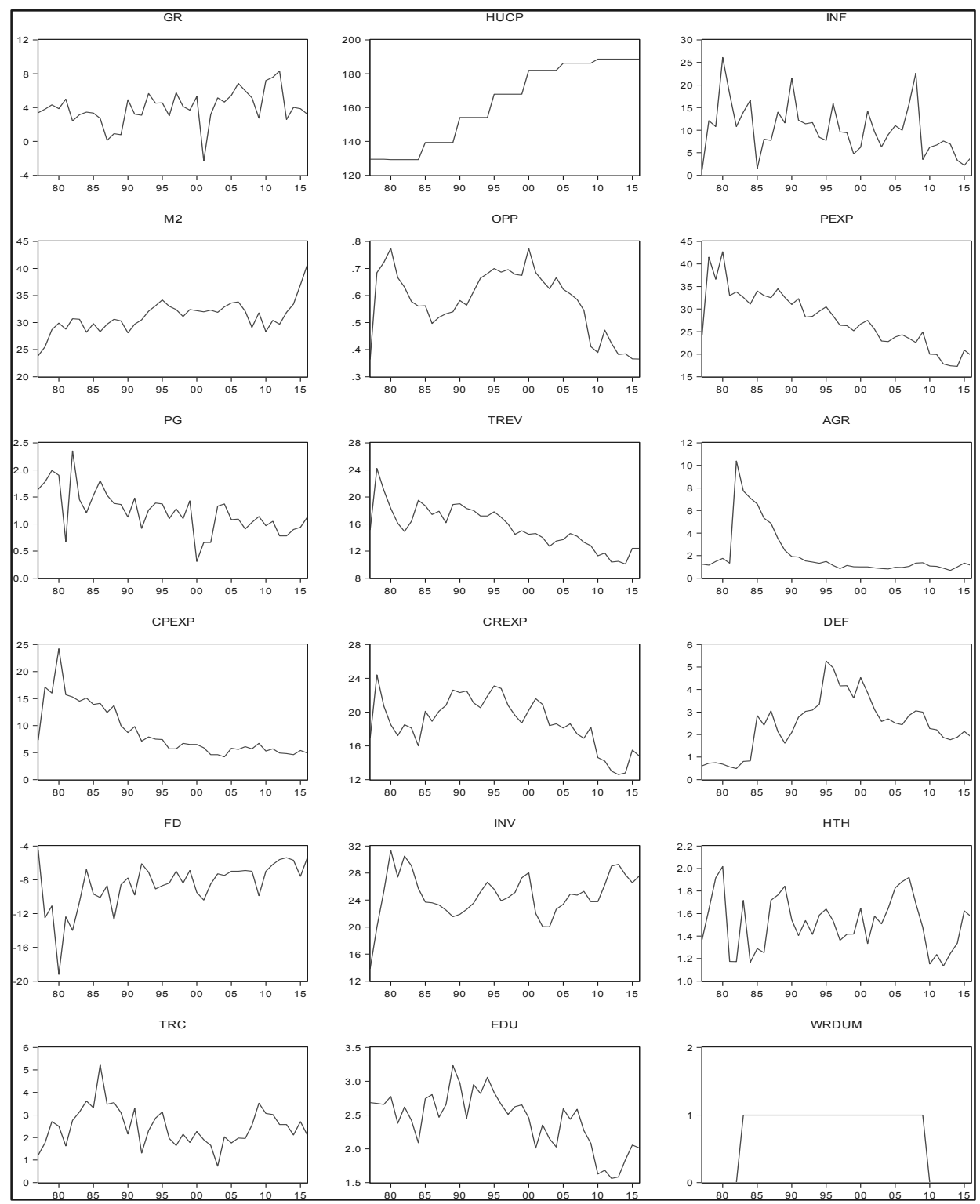

Note: The detailed descriptions of the variables are given in Table A1 
Table A1: Definition of the variables and data sources

\begin{tabular}{|c|c|c|}
\hline Variable & Definition of Variables & Data Source \\
\hline & GDP Data & \\
\hline \multirow[t]{2}{*}{ gr } & Growth rate of GDP & $\begin{array}{l}\text { World Bank Development } \\
\text { Indicators }\end{array}$ \\
\hline & Conditioning Variables (X) & \\
\hline inv & Gross fixed capital formation ( $\%$ of GDP) & $\begin{array}{l}\text { World Bank Development } \\
\text { Indicators }\end{array}$ \\
\hline pg & Population growth rate & DCS \\
\hline \multirow[t]{2}{*}{ hucp } & $\begin{array}{l}\text { Human capital (primary, secondary and tertiary school } \\
\text { enrolment ratio) }\end{array}$ & Barro and Lee (1994) \\
\hline & Control Variables (Y) & \\
\hline opp & Exports and imports share of GDP (trade openness) & CBSL \\
\hline $\mathrm{m} 2$ & Broad Money (M2) (\% of GDP) & CBSL \\
\hline $\inf$ & Inflation rate as the percentage change of $\mathrm{CPI}$ & DCS \\
\hline $\operatorname{gr}(-1)$ & One period lag of growth rate of GDP & CBSL \\
\hline \multirow[t]{2}{*}{ wrdum } & $\begin{array}{l}\text { Dummy variable to capture civil war } \\
\text { (1 for } 1983-2009 \text { and } 0 \text { for otherwise })\end{array}$ & \\
\hline & Fiscal Variables $(\mathrm{Z})$ & \\
\hline pexp & Public expenditure ( $\%$ of GDP) & CBSL \\
\hline $\operatorname{pexp}(-1)$ & $\begin{array}{l}\text { One period lag of public expenditure } \\
(\% \text { of GDP })\end{array}$ & CBSL \\
\hline rev & Government revenue (\% of GDP) & CBSL \\
\hline $\mathrm{fb}$ & $\begin{array}{l}\text { Fiscal Balance (surplus/deficit) (\% of GDP) } \\
\text { Components of Government Expenditure }\end{array}$ & CBSL \\
\hline edu & Government expenditure in education ( $\%$ of GDP) & CBSL \\
\hline hth & $\begin{array}{l}\text { Government expenditure in health expenditure } \\
(\% \text { of GDP })\end{array}$ & CBSL \\
\hline $\operatorname{trc}$ & $\begin{array}{l}\text { Government expenditure in Transport and Communication ( } \% \\
\text { of GDP) }\end{array}$ & CBSL \\
\hline agr & $\begin{array}{l}\text { Government expenditure in Agriculture and Irrigation } \\
(\% \text { of GDP) }\end{array}$ & CBSL \\
\hline \multirow[t]{2}{*}{ def } & Government expenditure in Defense ( $\%$ of GDP) & CBSL \\
\hline & Components of Government Revenue & \\
\hline trev & Tax revenue $(\%$ of GDP) & CBSL \\
\hline
\end{tabular}

Note: CBSL-Central Bank of Sri Lanka, DCS-Department of Census and Statistics of Sri Lanka

\section{A.2 Construction of human capital variable}

Literatures including Easterly and Rebelo (1993) and Barro and Sala-i-Martin (1999) uses enrolment rates for human capital variable. However, in this study, we follow Bose et al. (2007) to construct the initial human capital variable. In this study, the human capital variable is a weighted sum of initial enrolment ratios in primary, secondary and higher education. The weights are 1 for primary school, 2 for secondary school and 3 for higher education. Weights are approximations to the relative values of three types of education. The construction of the human capital variable is based on the Barro and Lee (2000) data source. 
Table A2: Descriptive statistics of the variables

\begin{tabular}{lcccccc}
\hline \hline Variable & Obs & Mean & Median & Min & Max & Std. Dev. \\
\hline gr & 40 & 5.1089 & 5.0999 & -1.5454 & 9.1446 & 1.9028 \\
pg & 40 & 1.0978 & 1.1750 & -2.2400 & 2.3500 & 0.8036 \\
opp & 40 & 0.5782 & 0.5958 & 0.3638 & 0.7741 & 0.1192 \\
hucp & 40 & 8.8883 & 9.3500 & 6.7200 & 10.3100 & 1.3528 \\
inv & 40 & 24.7176 & 24.7965 & 13.8298 & 31.3331 & 3.2970 \\
inf & 40 & 10.2500 & 9.6000 & 1.2000 & 26.1000 & 5.6426 \\
m2 & 40 & 31.1175 & 30.9000 & 23.9000 & 40.7000 & 2.8616 \\
pexp & 40 & 27.6475 & 27.1000 & 17.3000 & 42.7000 & 6.1954 \\
fb & 40 & -8.6025 & -8.1000 & -19.2000 & -4.5000 & 2.7945 \\
trev & 40 & 15.5325 & 15.0500 & 10.1000 & 24.2000 & 3.0780 \\
agr & 40 & 2.1499 & 1.2802 & 0.6945 & 10.3932 & 2.2363 \\
def & 40 & 2.4672 & 2.4729 & 0.4897 & 5.2692 & 1.2292 \\
edu & 40 & 2.4252 & 2.4886 & 1.5597 & 3.2320 & 0.4166 \\
hlth & 40 & 1.5174 & 1.5370 & 1.1337 & 2.0169 & 0.2395 \\
trc & 40 & 2.4758 & 2.4027 & 0.7229 & 5.2158 & 0.8352 \\
\hline
\end{tabular}

Note: The detailed descriptions of the variables are given in Table A1 in Appendix

Figure A2: Trends in public expenditure: disaggregated analysis

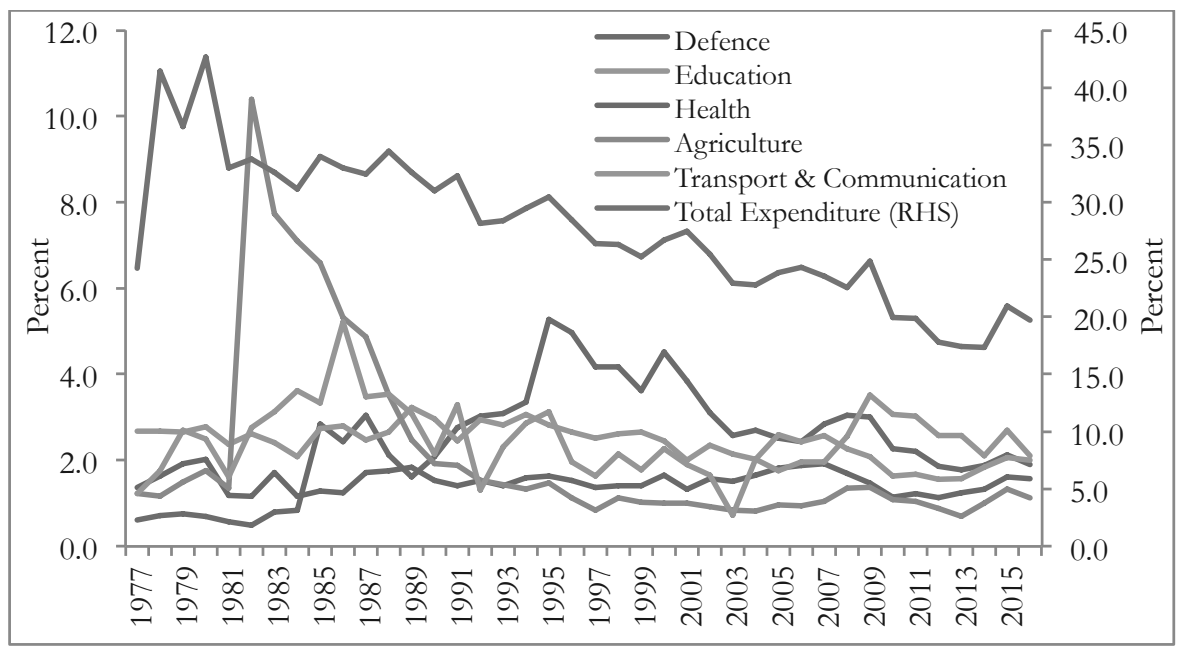

Source: Central Bank of Sri Lanka 
Table A3: Selection of optimal lag length

\begin{tabular}{ccccccc}
\hline \hline Lag & LogL & LR & FPE & AIC & SIC & HQ \\
\hline 0 & -659.7271 & NA & 59.4367 & 35.3014 & 35.7755 & 35.4701 \\
1 & -359.8285 & $410.3875^{*}$ & 0.0062 & 25.8857 & $31.5742^{*}$ & 27.9096 \\
2 & -183.9458 & 138.8548 & $0.0022^{*}$ & $22.9972^{*}$ & 33.9000 & $26.8763^{*}$ \\
\hline
\end{tabular}

Note: * indicates lag order selected by the criterion, LR: sequential modified LR test statistic, FPE: Final prediction error, AIC: Akaike information criterion, SIC: Schwarz information criterion, HQ: Hannan-Quinn information criterion (each test at $5 \%$ significance level)

Source: Author's Calculation

\section{A.3 Testing for structural breaks in public expenditure and economic growth}

As our sample involves the time period around the financial crisis of 2008 and the end of the civil war in 2009, we examined structural breaks in public expenditure (PEXP) and economic growth (GR). This study uses a global maximiser test introduced by Bai and Perron (2003) to determine the years of any structural breaks.

\section{Table A4: Identification of structural break for public expenditure}

Dependent Variable: PEXP

Method: Least Squares with Breaks

Sample (adjusted): 19812016

Break type: Bai-Perron tests of $\mathrm{L}+1$ vs. $\mathrm{L}$ sequentially determined breaks

Break selection: Trimming 0.15, Max. breaks 5, Sig. level 0.05

No breakpoints selected

\begin{tabular}{|c|c|c|c|c|}
\hline Variable & Coefficient & Std. Error & t-Statistic & Prob. \\
\hline $\operatorname{PEXP}(-1)$ & 0.560567 & 0.155598 & 3.602653 & 0.0011 \\
\hline $\operatorname{PEXP}(-2)$ & 0.119634 & 0.174111 & 0.687113 & 0.4971 \\
\hline $\operatorname{PEXP}(-3)$ & -0.002657 & 0.149258 & -0.017801 & 0.9859 \\
\hline $\operatorname{PEXP}(-4)$ & 0.233271 & 0.108040 & 2.159114 & 0.0387 \\
\hline \multicolumn{5}{|c|}{ Non-Breaking Variables } \\
\hline $\mathrm{C}$ & 1.446762 & 1.785148 & 0.810444 & 0.4239 \\
\hline R-squared & 0.877580 & \multirow{7}{*}{\multicolumn{2}{|c|}{$\begin{array}{l}\text { Mean dependent var } \\
\text { S.D. dependent var } \\
\text { Akaike info criterion } \\
\text { Schwarz criterion } \\
\text { Hannan-Quinn criter. } \\
\text { Durbin-Watson stat }\end{array}$}} & 26.69167 \\
\hline Adjusted R-squared & 0.861784 & & & 5.219654 \\
\hline S.E. of regression & 1.940532 & & & 4.292048 \\
\hline Sum squared resid & 116.7356 & & & 4.511981 \\
\hline Log likelihood & -72.25686 & & & 4.368810 \\
\hline F-statistic & 55.55670 & & & 1.892250 \\
\hline Prob(F-statistic) & 0.000000 & & & \\
\hline
\end{tabular}

Source: Author's Calculation 


\section{Table A5: Identification of structural break for economic growth rate}

Dependent Variable: GR

Method: Least Squares with Breaks

Sample (adjusted): 19812016

Break type: Bai-Perron tests of $L+1$ vs. $L$ sequentially determined breaks

Break selection: Trimming 0.15, Max. breaks 5, Sig. level 0.05

No breakpoints selected

\begin{tabular}{lllrl}
\hline \hline Variable & Coefficient & Std. Error & t-Statistic & Prob. \\
\hline GR(-1) & 0.225703 & 0.179749 & 1.255657 & 0.2186 \\
GR(-2) & 0.043694 & 0.183342 & 0.238320 & 0.8132 \\
GR(-3) & -0.031467 & 0.183389 & -0.171587 & 0.8649 \\
GR(-4) & -0.017750 & 0.180679 & -0.098240 & 0.9224 \\
& & & \\
Non-Breaking Variables & & & \\
& & & \\
C & 3.921429 & 1.537254 & 0.0159 \\
& & & \\
R-squared & 0.057263 & Mean dependent var & 5.037537 \\
Adjusted R-squared & -0.064381 & S.D. dependent var & 1.989329 \\
S.E. of regression & 2.052367 & Akaike info criterion & 4.404111 \\
Sum squared resid & 130.5786 & Schwarz criterion & 4.624044 \\
Log likelihood & -74.27400 & Hannan-Quinn criter. & 4.480874 \\
F-statistic & 0.470743 & Durbin-Watson stat & 1.998211 \\
Prob(F-statistic) & 0.756761 & & \\
\hline
\end{tabular}

Source: Author's Calculation 